\title{
Effects of the sale of real estate to foreigners in Turkey: settlements of Cappadocia and Silifke
}

\author{
H. Yakar \\ Yıldız Technical University, Faculty of Architecture, Istanbul, Turkey
}

\begin{abstract}
The acquisition of real estate by foreign private and legal entities in Turkey has continued with an increasing momentum in recent years, especially in the settlements bordering the Mediterranean and the Aegean Sea and in the important historical and tourist settlements. However, this became a significant problem in a different dimension due to the legal regulations made by the central and local governments from 2000 s to make the sales easier.

This study discusses this issue in two sub-regions; one of them is the "Rocky Cappadocian Region" which was inscribed in the UNESCO World Heritage List in 1985 and the other one is the "Silifke Settlement" in Mersin which is also one of the country's most important port cities. The emergent urbanization, environmental and planning problems in consequence of the acquisition of real estate by foreigners and both the common and the varied problems due to the geographical locations, features, and identities caused by sales have been accentuated in both the two sub-regions.

As a result, this study associates the evidences obtained from the analysis which had been made between 2001and 2005 in the "Rocky Cappadocian Region" and between 2006 and 2009 in the "Silifke Settlement" such as the rate of real estate sales to foreigners, distributions of these rates according to years and countries within the region with urbanization, environment and planning problems, and in this context emphasizes the negative effects of the evidence to tourism. Evaluating these results compared with the formations of the Member States of the European Union, this study focuses on the solutions in the context of planning and sustainable urbanization - tourism.
\end{abstract}

Keywords: sustainable urbanization - tourism, environmental problems (flood, earthquake, landslide). 


\section{Introduction}

The acquisition of real estate by foreign private and legal entities (in this study, the "foreign" concept includes the citizens of the Member States of the European Union) is an issue which is constantly on the agenda of Turkey after the year 2000 and it includes not only the problems of urbanisation and spatial development. Thus it is a very significant problem which has to be discussed in terms of social and economic dimensions.

Therefore, this study discusses these issues relating sustainability and tourism to the policies within the scope of foreigner law.

In the first part of the study the acquisition of real estate by foreigners has been discussed in terms of international law in the case of Turkey, and in the second part, the historical development of the acquisition of the real estate by foreigners in Turkey. The problems caused by the sold real estate in the case of the study area have also been discussed, and finally in the third part developed proposals have been mentioned regarding the policies of the member states of the European Union about the acquisition of real estate by foreigners.

\section{The "foreign" concept and international law in Turkey}

The rights granted to foreigners in international law which were defined as capitulations have been important throughout history [1]. In certain areas of the port and trade cities of Europe and the Near East during the Middle Ages, some privileges were common to foreigners such as residing freely and being tied to the laws of their home country.

In the period of the Ottoman Empire some privileges about real estate, trade, tax and judgment were first given to Genoese and Venetian traders, and then to foreigners from various countries such as France, The Netherlands and Switzerland [2].

However, the same rights had been requested by the local people because of this situation, so the social and economic tensions continued until the abolition of capitulations with the Treaty of Lausanne in 1923 [1].

Because of this, when a new law or amendment is on the agenda related with the granted rights to foreigners, such as the acquisition of real estate, various discussions emerge dating back to the Ottoman Empire.

The absence of a single basic law related with the rights granted to foreigners, also the existence of these laws within the scope of other different legislation, modifications and the correspondence between them about the rights granted to foreigners, especially about the sale of real estate, are the other causes of the contradictions in Turkey.

The new laws especially and the new modifications on existing laws which have been enacted after 2000 cause an ambiguity about the permissions of these sales.

As is seen from Table 1, even the priority conservation areas such as tourism, agricultural lands and treasury lands are allowed to be sold as real estate to foreigners on the occasion of the articles of existing laws and new enacted laws 
Table 1: Legal Regulations to support the real estate acquisition of foreigners.

\begin{tabular}{|l|l|l|}
\hline DATE & $\begin{array}{l}\text { NUMBER of } \\
\text { the LAW }\end{array}$ & NAME of the LAW \\
\hline $\mathbf{1 9 8 2}$ & $\mathbf{2 6 3 4}$ & The Tourism Promotion Law (article 8/E) \\
\hline $\mathbf{1 9 8 5}$ & $\mathbf{3 2 1 8}$ & The Free Zones Law (article 2) \\
\hline $\mathbf{2 9 . 6 . 2 0 0 1}$ & $\mathbf{4 7 0 6}$ & $\begin{array}{l}\text { The modification of the assessment of real } \\
\text { estate owned by the Treasury and value- } \\
\text { added tax law }\end{array}$ \\
\hline $\mathbf{2 0 . 1 2 . 2 0 0 3}$ & $\mathbf{5 0 1 5}$ & Petroleum Law \\
\hline $\begin{array}{l}\mathbf{0 3 . 0 7 . 2 0 0 3} \\
\mathbf{0 7 . 0 4 . 1 9 2 4}\end{array}$ & $\begin{array}{l}\mathbf{4 9 1 6} \\
\mathbf{4 4 2}\end{array}$ & Rural Law \\
\hline $\mathbf{0 5 . 0 6 . 2 0 0 3}$ & $\mathbf{4 8 7 5}$ & $\begin{array}{l}\text { Direct Support for the Foreign Investments } \\
\text { Law }\end{array}$ \\
\hline
\end{tabular}

according to the EU criteria, which have been approved by the council of ministers [2].

The reason why the issue of the sales of real estate to foreigners suddenly appeared on the agenda of Turkey after 2000 is the modification of an article of the land law which had been effectuated in 1934 about the acquisition of real estate by foreigners rather than the enacted laws according to the directives of the European Union. This law did not provide a constraint about the locations of the real estate which were to be sold to foreigners and it even removed the restrictions of the previous law increasing the quantity of real estate that was allowed to be sold.

In this context, although the debate is multidimensional, it has been polarized into two basic approaches. One of them supports the law intending to attract the foreign investments and to get the economic benefit as a result of globalization and the freedom of movement, and the other focuses on the issue arguing that marketing the lands of the country without a limitation will affect this region adversely in terms of the tourism sector, spatial and economic development.

However the constant discussion of this issue and the sceptical approach to every subject that includes the "foreign" concept do not only pertain to Turkey, due to the fact that the real estate indirectly related to "countryland and sovereignty" countries behave sceptically on this subject [3-5].

This is why the international law on foreigners includes the "Reciprocity Principle".

\section{1 "Reciprocity Principle" and the sale of real estate to foreigners}

Even though the purposes of the international law about foreigners differ, it has the "reciprocity principle" in itself; hence the international law is formed according to this concept [2].

Therefore, this subject has to be addressed in this context. In the face of the relationship between Turkey and the Member States of the European Union the 
"reciprocity" principle of relevant laws is just a written text. This principle has no validity in practice, because Turkey is not one of the Member States of the European Union.

Acquiring real estate in a foreign country is an extension of the demands such as travelling, working or settling in that country. Therefore, in this sense acquiring real estate from any of the Member States of the European Union is a natural process for the citizens of the Member States of the European Union with their foreigner identity. However, it is not possible to acquire real estate for a Turkish citizen (because of not being one of the Member States of the European Union) in contrast with the existence of the "reciprocity" principle. In fact, there is no freedom for Turkish citizens to move, travel and work in the Member States of the European Union. Hence, the existence and being brought up of the "reciprocity" principle in arguments is interesting in these conditions which does not include the mentioned freedom.

Even though there is such a double standard; broadening of the concept of this subject; selling real estate to foreigners in the context of the "reciprocity" principle is a legal, politics and planning problem that must be thought upon.

\section{The historical development of the selling of real estate to foreigners}

The acquisition of real estate by foreigners in Turkey can be analyzed periodically in three stages as follows; the period between 1934-2003 and 20032005 and after 2006.

37,342 properties were acquired by foreigners in the last 69 years, from the land registry law which was invoked in 1934, until its renewal at 2003 [6], (540 average real estate purchases per year). In July 2003, the 35th article of the land registry law was changed, foreign private and legal entities were given the permission to acquire real estate up to 30 hectares with the ordinance by the Council of Ministers and also there was no limit to the location of the estate. The foreigners that were not allowed to acquire any real estate in villages were given permission with this new article. From the date this new law was invoked in July 2003, until July 2005, when the law was denounced, in two years, 15,842 properties were purchased or sold by/to foreigners, which adds up to an average of 7,920 estates per year [6].

In 2006 the integrity of the law was changed and when it was invoked again, foreign private and legal entities were given permission to purchase real estate of up to 2.5 hectares. In sales of 2.5 hectares to 10 hectares, the purchase could be done with the ordinance of the Council of Ministers. The limit for the purchases that could be done with the ordinance of the Council of Ministers was lowered to 10 hectares from 30 hectares [7]. In the same law, the sales were forced to be $0.5 \%$ of the planned zones. No other limitations were made, no circumstances were indicated and a homogenous application was made in the whole country. 


\subsection{The distribution of real estate sold to foreigners throughout the country}

Despite the political and legal contradictions, the specifications of the real estate which are more important in terms of planning are their functions and sizes. In a sense, the functions and sizes of the real estate indicate the dispersion of the estates bought, amongst the regions.

In Turkey, considering the real estate bought by the foreigners, lots and land is the first with $84,95 \%$ in estate quantity. Examining the estates in terms of their acreage, it has been seen that, $30 \%$ of the estates are in Mediterranean Region and $29,5 \%$ are in the Aegean Region [8].

In this context, considering the quantity and acreage of the real estate bought by foreigners, it has been seen that $32 \%$ of the Aegean and Mediterranean Regions, which have an approximately $4000 \mathrm{~km}$. long coastline, are firstly chosen by foreigners to be bought for secondary housing, and $14 \%$ of them for tourism areas [9].

Aside from political and legal contradictions of this issue the contents of real estate in terms of planning are; their locations, functions and quantities.

In Turkey, among the real estate that foreigners acquire, first rank is lots and lands with $84.95 \%$, which indicates the location of the real estate in the habitat. 1 st and 2 nd in acreage in acquisition of real estate by foreigners are with $30 \%$ in Mediterranean and 29.5\% in the Aegean region.

Aegean and Mediterranean coasts have a coastline of about $4000 \mathrm{~km}$ and $28.50 \%$ of these shores have settlements. $54 \%$ of these settlements are urban areas, $32 \%$ are secondary housing and $14 \%$ are tourism zones.

The ranking in regions that foreigners choose to acquire real estate in is; 1 st Antalya, 2nd Mersin in the Mediterranean region and the important tourism settlements such as Muğla, Bodrum, Marmaris, Dalaman etc. in the Aegean region.

The acreage of the estates that foreigners acquire are, $6 \%$ workplaces, $2 \%$ touristic facilities, and their subdivision due to numbers which are, $3.47 \%$ workplaces and $0.52 \%$ touristic facilities, indicates that the estates are mostly secondary houses and land [10].

\subsection{Silifke Settlement and Rocky Cappadocian region}

Mersin, one of the study areas, is located in the Eastern Mediterranean; Rocky Cappadocian Region is located in Central Anatolia. Although the settlements mentioned above are in different regions, they are neighbour regions and have economical, cultural and social bonds. Both of these study areas are strong in land, rail and airborne transportation connections. Mersin Harbour is both a harbour and a free zone, which makes it one of the most important ports in the Mediterranean Sea.

Second of the common traits of both of the regions is their agricultural fertility. Mersin, especially Silifke, have fertile banana, strawberry, peanut and watermelon fields. Rocky Cappadocian Region has grape vineyards and both have fertile lands that have the potential for special products. Both study areas have been the home of many civilizations, Cappadocia has traces of prehistoric 
civilizations and later of the Hittites, also Silifke has the traces of the Roman Civilization which create the value of tourism of these settlements.

Adana Incirlik Air Base has an important role in the facing of both the two settlements with foreign investors and real estate buyers except for these common traits: Adana Incirlik Air Base was opened in 1955, located at a distance approximately equal to both the two settlements. American soldiers and personnel who work in the Adana Incirlik Air Base have an important role in the recognition of Silifke that they had discovered the settlement as a recreation town in summer. Likewise, employees of the Air Base which is approximately 3 hours away from Nevsehir Urgup had visited the Rocky Cappadocian Region before, and then they rented houses for weekends.

Except for foreigners, Silifke has always been a preferred settlement by the people who live in the other tourism settlements of Mersin province and also by the people who live in Central Anatolia, with its coastal towns, such as Gökbelen, Gülnar and Gözne plateaus and Erdemli, Tece.

The potentials of both of these two settlements have made this region attractive for foreigners to acquire real estate.

\subsubsection{Silifke}

The number of properties acquired by foreigners in Silifke is 397, and 301 of them were sold after 2004. In the case studies it has been found out that 290 of these 301 mentioned are in the secondary/summer housing area which is $9 \mathrm{~km}$ away from the centre of the settlement and it has also been found that the rest of the 11 properties are strawberry fields, and that the sizes of these areas respectively range from $1.5-2$ hectares [10].

308 of the total acquired real estate by foreigners in Silifke are in the secondary/summer housing area and the rest of the 17 are in the orchards and vineyards area.

$80 \%$ of the foreigners that acquired real estate are Germans, the worker immigration to Germany since the mid 1960s has a significant impact on this development. The relationship between the settlement and the people who went form Silifke had an influence on the relationship with Germany and Germans as well. After Germans, British and French are the 1st with 5\% and Swiss are the 2nd with 3\%, also the Netherlands and Finnish are the 3rd with $2 \%$ among the nations that acquired real estate from Silifke [10].

It has been found out by the interviews made with the people who purchased strawberry orchards that they had not bought the orchards for commercial purposes and will not use the area as a whole orchard; in fact they tend to use the area as a farm planning to spend their retirement times in this settlement.

\subsubsection{Rocky Cappadocian Region}

In Rocky Cappadocian Region, which is a sub-region of the Cappadocia Region, the situation differs in some points from Silifke.

Rocky Cappadocian Region is composed of Avanos, Urgup and Goreme settlements. It has been found out by the researches made that 187 real estate were acquired by foreigners and 180 of them are for residential, 4 of them are for commercial and 3 of them are for orchards and vineyards use. 
According to the ranking of foreigners, it consists of the French with $35 \%$, Belgians and Germans with $16 \%$ [11].

The sold houses in Rocky Cappadocian Region are located in the old city centre, in other words they are particularly located in the urban historical site where people reside in during both summer and winter.

\subsection{The assessment of the settlements in terms of the sold houses}

In evaluating the houses sold in Rocky Cappadocian Region and Silifke, it has been found out that the acquired real estate for secondary/summer house using in both of these two cases and they have been preferred from secondary housing area in Silifke and from the city centre in Cappadocian Region. The occurred problems differ according to the differentiation of the locations of these residential areas.

In Silifke, tendencies towards secondary housing on the coastal areas have led local administrations to new pursuits. In the past 10-15 years, Silifke local administrations (the same process has been followed in the other settlements) have filled swamps, morasses and stream beds in order to plan these areas for the construction of secondary/summer houses.

Certain research subjects such as the environmental problems which occur as a result of the swamps and morasses being filled, and the ecological balance, are not the content of this study, but vermin problems like flies, insects and most important of all, flooding, which occurs every winter as a result of the stream beds being filled, must be mentioned as dire planning problems [9].

In 2003 and 2007 especially, Silifke went through the largest flooding disasters in its history, as the secondary housing areas on its coasts suffered the heaviest damage. Luckily, there were no life-losses because the disasters happened in the period between October and November.

Increasing multi-story blocks of secondary housing destroyed the relationship between the coastal area and the city centre. Even though the summer season takes a long period of 3-4 months in the Mediterranean, the secondary housing areas remain as a big, empty and desolated area for the rest of the year creating a dark line in the coast which turns into a criminal area.

The infrastructures made by the local administrations for these secondary housing areas are already inadequate and which are out of use for the rest of the year and even for following years with a very limited budget, hence they have been left idle in an economic sense during this period.

The maintenance and repairs of the buildings which are not continuously used cannot be sustained without their residents. This has a negative effect on the area, causing the remaining residents to abandon the area, leaving it to dilapidation.

The problems caused by the acquiring of the real estate in Cappadocia add new ones to the problems in Silifke, because in the elder settlements like Avanos, Urgup, and Göreme, which are important touristic regions and also urban historical/archaeological sites, the local people cannot make their rockcarved or traditional houses repaired, maintained or restored due to their economical situations. 
Each of these houses is a cultural heritage by itself but what is more important than this is that they compose an urban pattern which must be protected in terms of both physical space and social structure. There are some rehabilitation and renewal projects of the local administration in the streets which have the mentioned pattern. At the beginning, acquiring of the real estate by foreigners from these streets made both the owners and local administrators pleased and even gave them hope to protect these streets, but afterwards it eventually caused new problems. These acquired houses were restored, repaired, maintained and prepared to live in by their new owners; their restored facades would soon give an aesthetic value to their streets, and later on to the city as a whole.

With this positive period, another subject of planning "gentrification" occurred, the rising prices, rents and the demands of the foreigners caused many of the local people to sell their houses to foreigners. Soon, the local people began abandoning the neighbourhoods and after that, the region.

After the abandoning process, these streets turned into a modal or a bunch of phantom streets, because of their foreign owners only stayed for a month at most and returned back to their home countries.

Furthermore, a few years later, local people encountered with the problem of inability to acquire a house in this region and began to put the pressure on the local governments to produce housing areas for them.

In fact, these settlements do not have a housing problem, just because of the emptiness of the existing houses and the demands of the local people to acquire new houses, an artificial problem of housing has emerged. The local administrators of Avanos and Urgup began to produce plans to transform the orchards and vineyards into cluster housing areas to solve this artificial problem of housing.

In an economic point of view, the supporters of the selling of the real estate to foreigners in touristic regions defend that by believing the regions will attract the foreign investments and increase the labour potential. However, the case studies that made in this region do not support this view.

Because a few years later, especially in the Rocky Cappadocian Region, secondary housing areas began to be used almost as boutique hotels by the people who were sent there by those estates' owners for vacation purposes, behind the excuse; the visitors of small groups' being their fellows or friends, so they literally started running unofficial tourism businesses in the residential areas of the city centre.

This situation somehow created an unrecorded and unjust income and economy, putting the local tourism and small-scale business and local touristic business in harm's way.

In both of the study areas, foreigners brought their repair and restoration projects and even some of their repair materials from their own countries, which made them useless for the local economy.

Another well known problem is the fact of the euro's superiority against Turkish lira, the currency of Turkey, which is not a member of the European Union. Foreigners with euro income, in time, raised the prices, especially in the 
eating-drinking sector and the local bazaar, forcing the locals who are unable to afford the higher prices to abandon the region.

As an important result of this, administrative staff who were assigned to security and educational duties by the central administrations through their own will, now make demands to leave the region immediately, because these people do not have enough income to afford living in these settlements. This situation causes an inadequacy in health and education service personnel, which causes the local people of the region to become victimized.

\section{The European Union and the restrictions to the acquisition of real estate by foreigners}

After the examination of the possible adverse effects of the unscheduled and uncontrolled acquiring of real estate by foreigners without an upper-scale planning process, also the approaches of the Member States of the European Union about this issue, have been analysed to compare them with each other. When the regulations of the Member States of the European Union and candidates on this subject are considered it has been seen that their approaches protect the politic and economic interests of their countries.

When the policies of some of these countries about the acquisition of real estate by foreign private and legal entities are examined it has been seen that there are some specific conditions and details such as $[12,13]$ :

- In Bulgaria, foreigners are only able to acquire the building itself, if there is a demand to also purchase the land by a company, it must be established according to the laws of Bulgaria

- Foreigners are not allowed to acquire agricultural and forestry land in Croatia, Russia and Ukraine

- If the Member States of the European Union sell the real estate that they had purchased before the acquired profit must stay in Greece

- In Spain, the foreigners (except the citizens of the Member States of the European Union) are not allowed to acquire the real estate from the islands which are smaller than $82.2 \mathrm{~km}^{2}$ and in the other regions the total area acquired by foreigners should not be exceed $15 \%$ of the total area of the region, this ratio is $10 \%$ in Kadiz Bay and Gibraltar and 5\% in North Africa

- In Hungary, foreigners are only allowed to acquire real estate in special conservation or agricultural areas through legal inheritance

- Foreign partnerships are subject to the special permission to acquire the real estate unless they have lived in Ireland for 7 years continually.

\section{Results and assessments}

Acquiring real estate is a natural process for the citizens who are not tied to the laws and allowed to work or settle in a country. Therefore, the acquisition of real 
estate by foreigners has to be addressed in the context of freedom of movement, residing and working [14].

Countries should not be considered homogeneous in fact there should be restrictions for the strategic and conservation areas or special areas due to various reasons in laws that determine the acquisition of the real estate by foreigners.

As it can be seen in the case studies, although it is not detailed for each geographical region the special conditions about the allowed ratio of the total area/unit to be acquired by foreigners, allowed duration to settle in the country or allowed/not allowed functions of the real estate to be changed must be specified for the whole country. Especially the acquiring and using conditions must be clarified for tourism, forestry and coastal areas, stream beds or for the centre of the city and the urban historical/archaeological sites.

Allowed conditions and restrictions about selling must be determined regarding the complexity of the economic structure, labour potential and development of different sectors, sustainable resources and environmental, urbanization, planning issues of the country.

As a result, the selling of real estate to foreigners must be considered not only in the context of legal regulations or economic and social influences, but also the integrity of planning related the national legal system in line with international practices, taking into account the political, economic and spatial interests of the country.

\section{References}

[1] Chatterjee, P., Ulus ve Parçaları, Kolonyal ve Post-Kolonyal Tarihler, Çeviren: İsmail Çekem, İletişim Yayınları, Istanbul, 1992

[2] Aybay, R., Yabancılar Hukuku, İstanbul Bilgi Üniversitesi Yayınları, Istanbul, 2005

[3] İmamoğlu, A. M., Azınlık Vakıfları ve Yabancıların Taşınmaz Edinimleri, Yazıt Yayıncıllk, Ankara, sy: 365, 2006

[4] Kurubaş, E., Asimilasyondan Tanınmaya, Uluslar arası Alanda Azınlık Sorunları ve Avrupa Yaklaşımı, Asil Yayın Dağıtım, Ankara, 2006

[5] Cem, İ., Avrupa'nın "Birliği” ve Türkiye, İstanbul Bilgi Üniversitesi Yayınları, Istanbul, 2005

[6] Kılıç, N., Yabancılara Gayrimenkul Satışı, Ar \& Ge Bülten, Araştırma ve Meslekleri Geliştirme Müdürlüğü, Izmir, 2006

[7] T.C., 2644 Sayıll, 1934 tarihli Tapu Kanununun 03.07.2008 tarihinde yürürlüğe giren yabancıların taşınmaz Mülk edinimini düzenleyen 35 . madde

[8] T.C. Cumhurbaşkanlığı Denetleme Kurulu, Yabancı Uyruklu Gerçek Kişiler ile Yabancı ülkelerde kurulanTüzel Kişiliğe Sahip Ticaret Şirketlerin Türkiye Cumhuriyeti Sınırları içinde Taşınmaz Edinimlerini Uygulamalarına ilişkin inceleme Raporu, 2009, www.tccb.gov.tr/ddk

[9] Erkan, N., Hamamcioglu. C., Eryilmaz, S., Akdeniz Kıyı kentlerinde tehditler ve Firsatlar: Silifke örneğinde ikinci konutların mekan kültürüne 
etkileri, Akdeniz üçlemesi, pp:181-193 ,KKK, Uluslararası Gazimagusa Sempozyumu, 2007

[10] Yenen, Z., Yakar, H., Erkan N., Hamamcıoğlu, C., Seçkin, E., Yıldız Teknik Üniveristesi, Mimarlık Fakültesi, Şehir ve Bölge Planlama Bölümü, Pl. Stüdyoları IV,V,VI kapsamında Silifke Yerleşmesi Araştırma Raporu, İstanbul, 2008

[11] Yakar, H., Özügül, D., "Kapadokya” da Kültürel Mekanı Etkileyen Yeni Dinamikler, pp:51-59, Yıldız Teknik Üniversitesi, Mimarlık Fakültesi, Şehir ve Bölge Planlama Bölümü yayını, 2003

[12] Harita ve Kadastro Mühendisleri Odası, Yabancılara Toprak Satış1, Neoliberalizmin Kıskacında Türkiye Toprakları, Harita ve Kadastro Mühendisleri Odası yayını, Ankara, 2006

[13] Uzun, B., Yoralığlu, T., Türkiye'de Yabancıların Taşınmaz Edinimi: Arazi Yönetimi Bağlamında Bir İnceleme, TMMOB, Harita ve Kadastro Mühendisleri Odası 11. Türkiye Harita Bilimsel ve Teknik Kurultayı, Ankara, 2007

[14] Yakar, H., Seckin. E., "Yabancilarin Taşınmaz Mülk Edinimi”, Akdeniz üçlemesi, pp:149-161, KKK, Uluslararası Gazimagusa Sempozyumu, 2007 